doi: 10.18575/msrs.sm.e.17.15 UDC 616.728.4-001-085 COBISS.RS-ID 6832152

\title{
Assesment of the Degree of Traumatic Lesions of Syndesmosis in the Functions of the Ankle Joint
}

\begin{abstract}
Introduction: An ankle joint is a modified hinged joint consisted of three bones and ligaments. Muscles that result in plantar, that is, dorsal flexion, work through this functional unit.
\end{abstract}

Aim of the Study: The aim of the paper is to analyze injuries of supra-syndesmotic fractures of the fibula, which were treated operatively with or without syndesmotic screw as well as to evaluate clinical results of the treatment after 3, 6 and 12 months.

Patients and Methods: A retrospective-prospective study consisted of 102 respondents treated at the Clinic for Orthopedics and Traumatology UCC Sarajevo. Patients were divided into two groups. The first group (G1) consisted of 48 (47\%) respondents who had met the required criteria - placement of a syndesmotic screw during the operation, and the second group (G2) consisted of 52 (53\%) respondents who did not have a syndesmotic screw inserted during the operation.

Results: The average value of the AOFAS score after 12 months in the group G1 was 91.15 points. The average value of the AOFAS score in the group G2 was 89.15 points. The value of the T-test was 1.688, $p=0.095$ ( $p>0.05)$. There was no significant difference in the average AOFAS score between the $\mathrm{G} 1$ and $\mathrm{G} 2$ respondents.

Conclusion: The results obtained in the study confirm that there is no significant difference in the final outcome of the treatment between the G1 and G2 respondents. There is no significant difference in duration of treatment and hospitalization between groups G1 and G2. Significantly better average values regarding mobility for patients in the group G2 during the check-ups 3 and 6 months after the surgical procedure were transient.

Key words: supra-syndesmotic fracture of the fibula, syndesmotic screw

(Scr Med 2017:48:108-113)
Fuad Džanković ${ }^{1}$, Goran Talić ${ }^{2,3}$, Amra Macic-Džanković ${ }^{4}$, Luka Talićc Mirza Bišćević ${ }^{1}$

${ }^{1}$ Clinic for Orthopedics and Traumatology, University Clinical Center Sarajevo

${ }^{2}$ Institute of Physical Medicine and Rehabilitation „Dr Miroslav Zotovic"Banja Luka

${ }^{3}$ Faculty of Medicine of University of Banja Luka

${ }^{4}$ Faculty of Health Studies, the University of Vitez

\section{Contact address:}

Fuad Džanković

Clinic for Orthopedics and Traumatology, University Clinical Center Sarajevo Street address: Bolnicka 25 7100 o Sarajevo Bosnia i Herzegovina e-mail: fuaddzankovic@hotmail.com phone number: +387-61-394-595

Submitted: May $8^{\text {th }}, 2017$ Accepted: June $12^{\text {th }}, 2017$

\section{Introduction}

The ankle joint is a modified hinged joint consisting of three bones and ligaments. ${ }^{1}$ Muscles that result in plantar, that is, dorsal flexion, work through this functional unit. ${ }^{1-}$ 3 A talus, which is latero-laterally determined by the position of the inner and outer malleolus is a main part of 
the ankle joint. The lower end of the tibia has an articulate surface corresponding to the talus, and it continues with a medial malleolus projected under the pylons and merges with the inner surface of the talus. ${ }^{4}$ The outer malleolus, which forms the lower end of the fibula, is projected about $1 \mathrm{~cm}$ distally and in the back in relation to medial malleolus, and it has an articulate surface corresponding to the talus. ${ }^{4,5}$ These bony articular structures connect medial and lateral collateral ligaments and ligaments of tibiofibular syndesmosis. The joint components of the joint are stabilized with three ligament complexes: the lower tibiofibular complex, the medial and lateral collateral ligament complex. ${ }^{5}$

Malleolar fractures are one of the most common fractures and account for about $10 \%$ of all fractures. ${ }^{6,7}$ The mechanism of syndesmotic lesion involves the force of external rotation applied to the foot in relation to tibia. Injuries to the syndesmosis may be purely a lesion of the ligament followed by a fracture. There are two most commonly used systems for the classification of malleolar fractures - the Danis-Weber (or AO classification), which is a morphological classification, and the LaugeHansen classification describing the mechanism of a fracture formation, i.e. the position of the foot before the action of the force and its movement under the effect of force. ${ }^{8,9}$ Associated fractures include pronation - external rotation of the hinge fracture (Weber type C), supinationexternal rotation of the hinge fracture (Weber type B) and proximal fibulae (Maisonneuve) fractures. ${ }^{8}$

\section{Aim of the Study}

The aim of the paper is to analyze injuries of suprasyndesmotic fractures of the fibula, which were treated operatively with or without syndesmotic screw as well as to evaluate clinical results of the treatment after 3, 6 and 12 months.

\section{Patients and Methods}

A retrospective-prospective study consisted of 102 respondents treated at the Clinic for Orthopedics and Traumatology UCC Sarajevo from January $1^{\text {st }}, 2005$ to January $1^{\text {st }}, 2016$.

The study included patients with the Weber C fracture, without comorbidity, who regularly responded to the controls. Patients were divided into two groups. The first group (G1) consisted of 48 (47\%) respondents who had met the required criteria - placement of a syndesmotic screw during the operation, and the second group (G2) consisted of $52(53 \%)$ respondents who did not have a syndesmotic screw inserted during the operation. The average age of the respondents in this study was
51.09 years and they were monitored for 61,62 months averagely. At the admission, a native radiography in the antero-posterior (AP) and latero-lateral (LL) projection with the foot in a neutral position was performed in all patients. A median clear space (MCS) and a tibiofibular clear space (TFCS) measurement at proximity of $1 \mathrm{~cm}$ proximal from the tibial plafond was conducted on each patient during the native radiogram in the AP projection.

We compared the clinical results of the respondents in G1 and G2 after 3, 6 and 12 months. After 12 months, we compared the results obtained with the AOFAS score by group. The research methods used the analysis of the database of the Clinic for Orthopedics and Traumatology UCC Sarajevo: electronic and paper forms, history of diseases, discharge summary, questionnaire and patients' check-up as predicted by the AOFAS score. ${ }^{10,11}$ Nonparametric $\times$ 2-test and, where necessary, the Fisher's exact test were used to test the differences in categorical dependent variables.

\section{Results}

The results were obtained using the American Ortopaedic Foot and Ankle Society score (AOFAS). ${ }^{10,11}$ The study consisted of 58 (57.87\%) male respondents and 44 (43.13\%) female respondents. In $\mathrm{G} 1$, there were 32 male and 16 female respondents, while in G2 there were 28 male and 26 female respondents. There was no significant difference in gender according to this this statistical variable. $\left(\mathrm{X}_{2}=3.553 ; \mathrm{p}=0.059<0.05\right)$

$33(32 \%)$ respondents were injured in the winter, 31 (31.06\%) in the summer, 22 (21.21\%) during autumn and $16(15.90 \%)$ in the spring. There were 18 (17.65\%) respondents born between 1930 and 1950; in both $\mathrm{G} 1$ and G2, there were 9 respondents. There were 43 (42.16\%) respondents born between 1951 and 1970; 22 in G1 and 21 in G2. There were 41 (40.20\%) respondents born between 1971 and 1990, 20 in G1 and 21 in G2. There was no statistically significant difference in age groups according to this variable. $(\mathrm{X} 2=1.701 ; \mathrm{p}=0.427>0.05)$ There were more female respondents in the age group born between 1930 and 1950 and there was a statistically significant difference $(\chi 2=6.266 ; p=0.044)$.

In the study, according to the Lauge Hansen classification, $83(81.37 \%)$ respondents were injured by the mechanism of pronation-external rotation (P-E). Out of that number, 42 respondents were in $\mathrm{G} 1$ and 41 respondents in G2. According to the same classification, 8 (7.84\%) respondents, 4 in $\mathrm{G} 1$ and 4 in G2, were injured by the mechanism of pronation- abduction (P-A). Eight patients were injured by the mechanism of supination-external rotation (S-E); Out of that number, 5 respondents were 
in $\mathrm{G} 1$ and 3 in G2. In total, $89.21 \%$ of respondents were injured by the rotary mechanism of injury and $3(2.94 \%)$ were injured by the compression mechanism. Groups G1 and G2 did not differ significantly in the mechanism of injuries. (Fisher $=4.240 ; p=0.253>0.05$ ). There was no significant difference between the genders according to this variable. (Fisher $=3.990 ; p=0.267>0.05$ ).

In $\mathrm{G} 1$, that is, in 48 (47\%) respondents, the transient syndesmotic screw was implanted through three cortical bones with cortical screws with a diameter of $3.5 \mathrm{~mm}$, at a height of $1 \mathrm{~cm}$ above the line of the joint. The average removal time of the syndesmotic screw was 10.6 weeks after the placement, and the length of hospitalization was 12.47 days. An acceptable reduction of syndesmosis was not achieved in the postoperative RTG in 4 (8.33\%) out of 48 respondents in $\mathrm{G} 1$ who had had the syndesmotic screw implanted according to the above mentioned parameters.

The average value of MCS patients in G1 was 3.63 millimeters while in G2, it was 2.94 millimeters. The value of the T-test was 2.214; $\mathrm{P}=0.029, \mathrm{p}<0.05$, and there was a significant difference in terms of higher average medial clear space in patients from G1. There was also a significant difference between genders according to the MCS $(t=2.962 ; \mathrm{p}=0.004)$, which was higher in male patients. The average values of TFCS of G1 patients were $5.42 \mathrm{~mm}$ and $4.98 \mathrm{~mm}$ in G2 patients. The value of the T-test was 2.476; $\mathrm{P}=0.15$ so $\mathrm{p}<0.05$. There was a significant difference in TFCS between the groups in terms of significantly higher TFCS of patients in the G1 group. There was also a significant difference between genders according to MCS $(t=2.440 ; p=0.016)$ in terms of higher TFCS in male patients. There was no statistically significant difference in average values of this variable between the age groups $\mathrm{G} 1$ and $\mathrm{G} 2(\mathrm{~F}=0.024$; $\mathrm{p}$ $=0.976>0.05$ ).

On the control check-up 3 months after the surgery, the mobility at the sagittal level was evaluated. The grade "contracture", which implied a mean or significant contracture received 63 respondents; $43(89.58 \%)$ in G1 and 20 in G2 (38.46\%). The "minimum contracture" grade was received by 27 respondents; 5 (10.41\%) in G1 and $22(42.31 \%)$ in G2. Total mobility was present in $12(23.08 \%)$ respondents from G1. Groups G1 and G2 differed significantly $\left(\chi_{2}=30.584 ; p=0.00<0.05\right)$. Respondents from the G2 group had a significantly better mobility during the follow-up 3 months after the surgery. There was no significant difference between genders according to this variable $(\chi 2=0.813 ; \mathrm{p}=0.066>0.05)$.

On the check-up conducted 6 months after the surgery, the mobility and support of the operated leg was evaluated. The grade "full support and full mobility" was received by 46 (45.09\%) respondents; 18 (17.65\%) from G1 and 28 (53.85\%) patients from G2. 3 (2.94\%) respondents, 2 from G1 and 1 from G2 had "painful full support, minimum contracture". The grade "full support, minimum contracture" was received by 8 respondents (7.84\%) from the G1 group. The grade "minimally painful full support, full mobility" was received by 11 (10.78\%) respondents out of which 2 were from G1 and 9 from G2. The grade "occasionally painful full support, minimal contracture" was present in 2 respondents, one in both groups. 25 (24.51\%) respondents had a "minimum painful full support and minimum contract" grade, that is, 17 (35.42\%) respondents from G1 and 8 (15.38\%) respondents in $\mathrm{G} 2$.

The grade "minimally painful full support, contracture" was present in 1 respondent from the G2 group, while the grade "periodically painful full support, full mobility" was received by 1 respondent from G2. Groups G1 and G2 were significantly different 6 months after the surgery (Fisher $=14.000 ; p=0.037<0.05)$ in terms of better results of the G2 patients. There was a significant difference between genders according to this variable (Fisher $=14.000 ; p=0.037$ ) in favor of male respondents .

At the control check-up twelve months after the surgery (Graph 1), a total of 54 (52.94\%) respondents received the grade "full support and full mobility", out of which 26 respondents (54.17\%) were from G1 and 29 (55.77\%) from G2. The grade "minimum pain support, minimum contract" was given to 3 respondents, 1 respondent from G1 and 2 respondents from G2. 4 respondents from the G1 group received the grade "full support, minimal contact”.

Graph 1. Analysis of G1 and G2 patients according to the results of check-up 12 months postoperatively

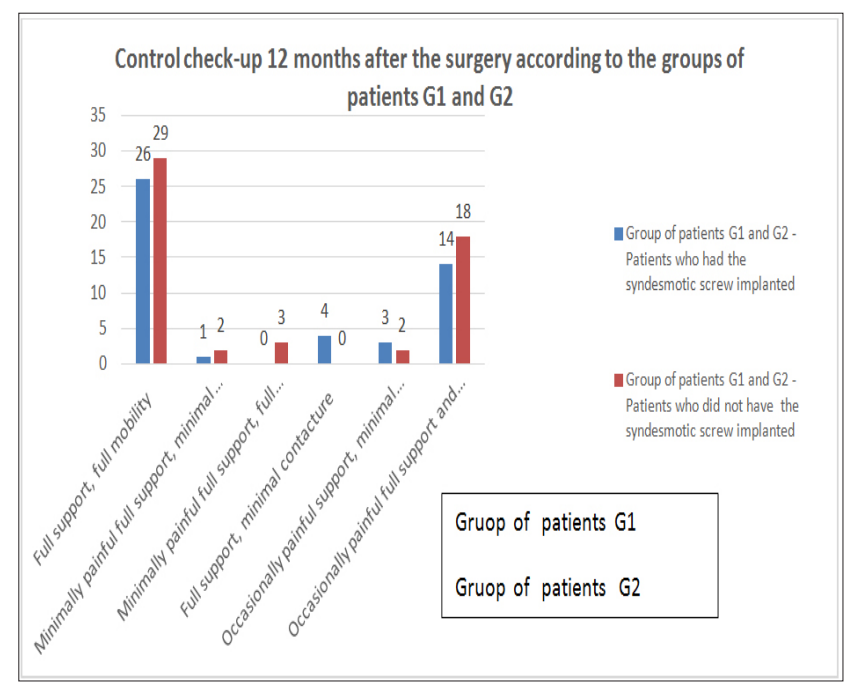

The rating "occasional painful support, minimum 
contracture" was given to 5 respondents, 3 respondents from the G1 group and 2 from the G2 group. The rating "occasionally painful full support and full mobility" received 32 (31.37\%) respondents, out of which 14 (29.17\%) were from $\mathrm{G} 1$ and 18 (34.61\%) were G2 respondents. Groups G1 and G2 did not differ. (Fisher $=8.976 ; \mathrm{p}=0.074<0.05)$. There was no significant difference in genders according to these variables (Fisher $=8.976 ; \mathrm{p}=0.074)$. From the above mentioned, it can be seen that 12 months after the surgery, there was no significant difference between the groups. A significant difference during the check-ups 3 and 6 months after the surgery was in favor of the G2 group but it was transient as there was no significant difference according to the given variables.

Graph 2. Analysis of all patients according to the value of AOFAS score

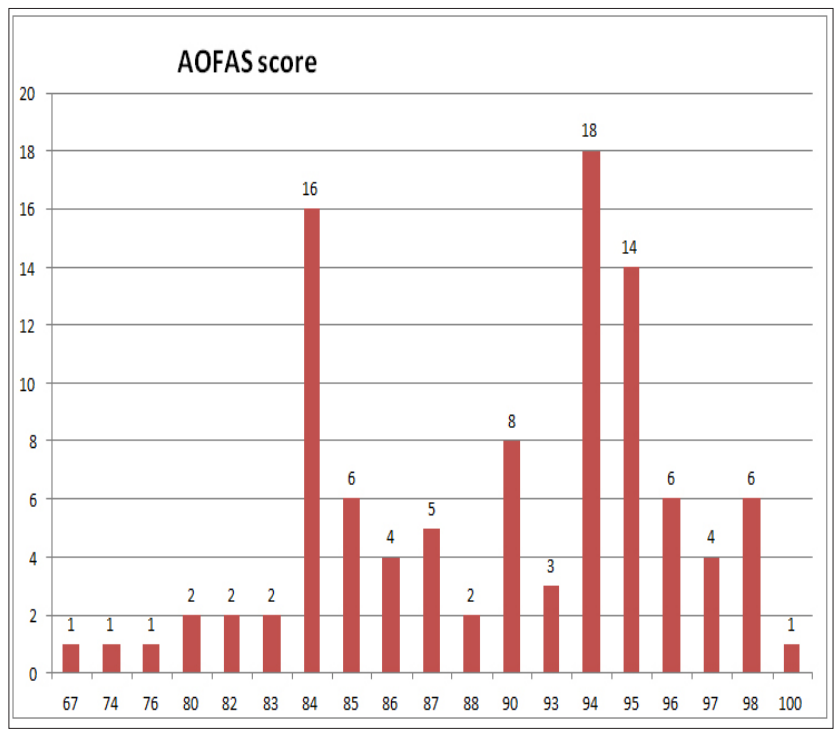

The average AOFAS score of the respondents from the group G1 after 12 months was 91.15 points. The average AOFAS score of the G2 respondents was 89.15 points. The value of the T-test was 1.688, $\mathrm{p}=0.095$ ( $\mathrm{p}>0.05)$. There was no significant difference in the average AOFAS score between the G1 and G2 respondents (Figure 2).

\section{Discussion}

In the study conducted by Kennedy JG and associates, there were 45 respondents with the same or similar characteristics as in our study. The respondents were divided into two groups: G1(36 respondents) and G2 (19 respondents). ${ }^{12}$ In the study conducted by Weening $\mathrm{B}$ and Bhandari $\mathrm{M}$, there were 51 subjects with Weber $\mathrm{C}$ fracture and the supplemental application of syndesmotic screw..$^{13}$ In this study, there were 48 such patients out of a total of
102 patients with Weber C fracture.

In the study conducted by Weening B and Bhandari M, the average age of patients was 40.6 years. ${ }^{13}$ The average follow-up time in their study was 18 months, while in in this study, it was 61 months.

In the study by Schepers and others, which was conducted at the national level of the Netherlands, a total of 9 studies included 531 patients with disturbances of distal tibiofibular syndesmosis. ${ }^{14}$ The average monitoring period ranged from 12 months to 101 months. The average values of the AOFAS score for patients with an immobilization period of 6 weeks (as in this study) were 86-91. The average AOFAS score for patients with an early mobilization was $84-89 .{ }^{13}$ There was no significant difference in the average values of the final functional results of the patients from these two different protocols of rehabilitation.

In the series conducted by Brown OL and associates, out of 88 surgically treated patients with a fracture of the ankle joint and associated syndesmotic lesion, about 90\% of patients successfully returned to earlier activities "several years" after the surgery, but only $71 \%$ returned to sports activities. ${ }^{14}$

\section{Conclusion}

Supra-syndesmotic fracture of the lateral malleolus with the lesion of the deltoid ligament is unstable and is an absolute indication for the application of syndesmotic screw. The decision on the application of the screw can be made preoperatively. In the supra-syndesmotic fracture of the lateral malleolus associated with the median malleolus fracture, the definitive decision on the application of the syndesmotic screw is made exclusively intraoperatively using the "stress test".

The results obtained in the study confirm that there is no significant difference in the duration of treatment and hospitalization in the final outcome of treatment between the G1 and G2 group respondents. Significantly better average mobility values for the respondents from G2 in post-operative 3 and 6 months follow-up were transient.

The respondents with inadequate syndesmotic reductions in application of syndesmotic screw have a statistically lower mean AOFAS score when compared to the respondents with adequate syndesmotic reductions.

\section{Reference}

1. NiinimäkiTT, KlemolaTM, LeppilahtiJI.Tibiotalocalcaneal arthrodesis with a compressive retrograde intramedullary nail. A report of 34 consecutive patients. Foot Ankle Int. 
2007; 28: 431-434.

https://doi.org/10.3113/FAI.2007.0431

PMid:17475136

2. Hiller CE, Kilbreath SL, Refshauge KM. Chronic ankle instability: evolution of the model. $\mathrm{J}$ Athl Train. 2011; 46:133-141.

https://doi.org/10.4085/1062-6050-46.2.133

PMid:21391798

PMCid:PMC3070500

3. Stufkens SA, van den Bekerom MPJ, Kerkhoffs GM, Hintermann B, van Dijk CN. Long-term outcome after 1822 operatively treated ankle fractures: a systematic review of the literature. Injury. 2011;42:119-127. doi:10.1016/j.injury.2010.04.006 https://doi.org/10.1016/j.injury.2010.04.006

4. Mandi DM. Ankle fractures. Clin Podiatr Med Surg. 2012;29:155-86. doi: 10.1016/j.cpm.2012.01.002 https://doi.org/10.1016/j.cpm.2012.01.002

5. Miller AG, Margules A, Raikin SM. Risk factors for wound complications after ankle fracture surgery. J Bone Joint Surg Am. 2012;94:2047-52. https://doi.org/10.2106/JBJS.K.01088 PMid:23172322

6. SooHoo NF, Krenek L, Eagan MJ, Gurbani B, Ko CY, Zingmond DS. Complication rates following open reduction and internal fixation of ankle fractures. $J$ Bone Joint Surg Am. 2009;91:1042-9. https://doi.org/10.2106/JBJS.H.00653 PMid:19411451

7. Thomsen N, Overgaard S, Olsen L, Hansen H, Nielsen S. Observer variation in the radiographic classification of ankle fractures. Bone Joint J. 1991;73:676-8

8. Mohammed R, Syed S, Metikala S, Ali S. Evaluation of the syndesmotic-only fixation for Weber-C ankle fractures with syndesmotic injury. Indian J Orthop. 2011;45(5):454458.

https://doi.org/10.4103/o019-5413.83953

PMid:21886929

PMCid:PMC3162684

9. Lauge-Hansen N. Fractures of the ankle.IV. Clinical use of genetic Roentgen diagnosis and genetic reduction. AMA Archives Surg. 1952;64:488-500.

https://doi.org/10.1001/archsurg.1952.01260010504008 PMid:14902249

10. Albano D, Martinelli N, Bianchi A, Messina C, Malerba F, Sconfienza LM. Clinical and imaging outcome of osteochondral lesions of the talus treated using autologous matrix-induced chondrogenesis technique with a biomimetic scaffold. BMC Musculoskelet Disord. 2017 Jul 18;18(1):306.

https://doi.org/10.1186/s12891-017-1679-x

PMid:28720091

PMCid:PMC5516391

11. Daly PJ, Fitzgerald RH Jr., Melton LJ, et al. Epidemiology of ankle fractures in Rochester, Minnesota. Acta Orthop Scand. 1987 Oct; 58:539-44. https://doi.org/10.3109/17453678709146395 PMid:3425285

12. Kennedy JG, Soffe KE, Dalla Vedova P, Stephens MM, O'Brien T, Walsh MG, McManus F. Evaluation of the syndesmotic screw in low Weber $\mathrm{C}$ ankle fractures. $\mathrm{J}$ Orthop Trauma. 2000 Jun-Jul;14(5):359-66. https://doi.org/10.1097/00005131-200006000-00010 PMid:10926245

13. Weening B, Bhandari M. Predictors of Functional Outcome Following Transsyndesmotic Screw Fixation of Ankle Fractures. J Orthop Trauma. 2005;19:102-108. https://doi.org/10.1097/00005131-200502000-00006 PMid:15677926

14. Schepers T, at all. The management of acute distal tibiofibular syndesmotic injuries. Results of a nationwide survey. Injury. 2012 Oct; 43 (10):1718-23. https://doi.org/10.1016/j.injury.2012.06.015 PMid:22795845

15. Brown OL, Dirschl DR, Obremskey WT. Incidence of hardware-related pain and its effect on functional outcomes after open reduction and internal fixation of ankle fractures. J Orthop Trauma. 2001; 15:271-4. https://doi.org/10.1097/00005131-200105000-00006 PMid:11371792 


\section{Procjena stepena traumatskih lezija sindezmoze na funkciju skočnog zgloba}

\section{SAŽETAK}

Uvod: Skočni zglob je modifikovani šarnirni zglob koga sačinjavaju tri kosti i ligamenti. Preko ove funkcionalne jedinice djeluju mišići koji dovode po plantarne, odnosno dorzalne fleksije stopala.

Cilj rada: Analizirati povrede suprasindesmotskog prelome fibule, operativno liječenih sa ili bez sindesmotskog šrafa i evaluirati kliničke rezultate liječenja nakon 3, 6 i 12 mjeseci.

Ispitanici i metode: U ovoj retrospektivno-prospektivnoj studiji učestvovala su 102 ispitanika liječena na Klinici za ortopediju i traumatologiju UKC Sarajevo.Pacijenti su podjeljeni u dvije grupe. Grupu jedan (G1) činilo je 48(47\%) ispitanika koji ispunjavaju tražene kriterije - u toku operacije postavljen je sindesmotski šraf, a grupu dva (G2) sačinjavala su 52(53\%) ispitanika kod kojih u toku operacije nije postavljen SŠ.

Rezultati: Prosječna vrijednost AOFAS skora nakon 12 mjeseci ispitanika grupe G1 je bila 91,15 poena. Prosječna vrijednost AOFAS skora ispitanika G2 je bila 89,15 poena. Vrijednost t-testa je bila 1,688, $p=0,095$ ( $p>0,05$ ). Nema značajne razlike prosječnih vrijednosti AOFAS skora između ispitanika grupa G1 i G2.

Zaključak: Rezultati dobijeni u studiji potvrđuju da nema značajne razlike u konačnim rezultatima liječenja između ispitanika grupa G1 i grupe G2. Nema značajne razlike u dužini trajanja liječenja i hospitalizacije između grupa G1 i G2. Značajno bolje prosječne vrijednosti pokretljivosti pacijenata grupe G2 na kontrolnim pregledima 3 i 6 mjeseci nakon operativnog zahvata bile su prolaznog karaktera.

Ključne riječi: sindesmotski prelom fibule, sindesmotski šraf 